
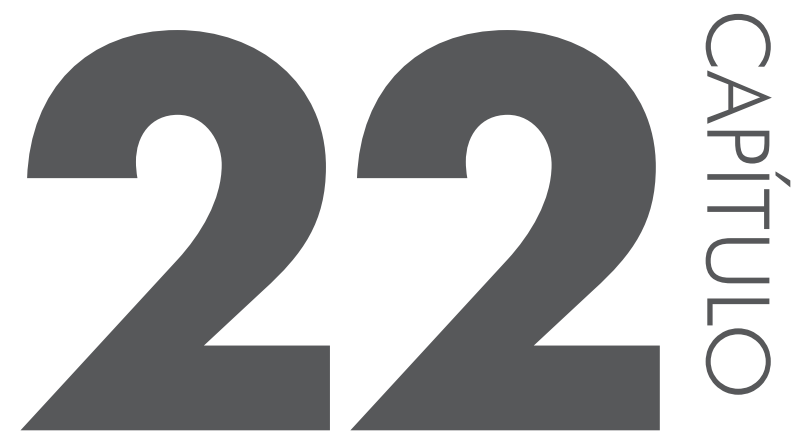

\title{
Representações sobre os africanos em livros didáticos brasileiros de história
}

\author{
Sueli de Cássia Tosta Fernandes \\ Secretaria da Cultura de Barretos, SP \\ Cristine Gorski Severo \\ Universidade Federal de Santa Catarina
}

[...] o longo hábito de não pensar que uma coisa seja errada lhe dá o aspecto superficial de ser certa, e ergue de início um temível brado em defesa do costume. Mas o tumulto não tarda arrefecer. O tempo cria mais convertidos do que a razão (Paine, 1964, p. 3).

Este capítulo tem como objetivo analisar o uso dos termos "escravo" e "escravizado" em livros didáticos (LDs) de história. Os seus significados dicionarizados em comparação com o contexto de uso foram observados para que pudéssemos refletir sobre os sentidos específicos que mobilizam. Consideramos que a oscilação verificada no uso dos dois termos aponta para relações de poder coloniais que se inscrevem linguisticamente na seleção lexical feita pelos autores dos livros. Esses dois termos apontam para duas interpretações diferentes: enquanto "escravo" tende a naturalizar a condição de exploração, "escravizado" nos remete a relações de poder e de subjugação, explicitando a dimensão política e colonizadora da escravização. Tal problematização lexical é fundamental, es- 
pecialmente após o sancionamento das leis 10.639 de 2003 e 11.645 de 2008, que tratam da obrigatoriedade de inclusão da temática "história e cultura afro-brasileira e indígena" nos currículos da educação brasileira. Acreditamos que, além do conteúdo, a linguagem utilizada para se falar desses conteúdos também é reveladora dos embates políticos envolvendo a população afro-brasileira. No caso deste capítulo, atenta-se para o papel da forma linguística na ratificação de estereótipos coloniais envolvendo os africanos no Brasil.

Ressalta-se que esta pesquisa resulta da dissertação de mestrado Racismo nos livros Didáticos (UFSCar), defendida por Fernandes em 2013. A pesquisa foi motivada, inicialmente, por um certo mal-estar suscitado pela leitura do texto intitulado Os africanos, presente no caderno de história de um aluno, em 1934. O caderno pertence ao acervo do Museu Histórico, Artístico e Folclórico Ruy Menezes, do município de Barretos, estado de São Paulo. O mal-estar provocado pela leitura do texto Os africanos se deu pela construção ideológica que associava os africanos à selvageria, transferindo a culpa pelo tráfico negreiro aos próprios africanos, e pela ideia de indenização, uma vez que mencionava que os africanos viviam no Brasil em melhores condições que os seus compatriotas que viviam em África. Para problematizar essa questão, buscou-se analisar a maneira como os livros didáticos reforçam visões estereotipadas sobre os africanos no Brasil. Para tanto, a presente pesquisa elegeu como alvo de análise três períodos históricos: Era Vargas, período militar (1964-1985) e democracia. A escolha por esses três períodos justifica-se pelo interesse em averiguar de forma comparada o percurso histórico de uso dos termos escravo vs. escravizado, bem como expressões correlatas, analiando a maneira como a língua inscreve relações de poder.

O corpus foi levantado junto a diferentes órgãos públicos do munícipio de Barretos, SP. Para esta pesquisa, utilizamos um caderno e oito livros didáticos que foram obtidos junto ao museu municipal, à biblioteca municipal e à diretoria regional de ensino. Dentre os autores de LDs, identificamos Joaquim Silva, como um dos mais utilizados pelas escolas entre as décadas de 1930 e 1950; e Elza Nadai, como a autora mais adotada no final da década de 1970 e nas décadas seguintes e que permaneceu no ranking dos LDs até o final da década de 1990 (MOREIRA, 2012). Quanto aos livros produzidos após a Lei 11.645, utilizamos a base de dados do Programa Nacional do Livro Didático (PNLD) para o triênio 2011-2013. Os livros correspondentes à seleção foram obtidos junto à editora Saraiva.

Sobre o papel do léxico na construção de sentidos, defende-se que as palavras operam como indicadores sociais, sendo vistas como "o fenômeno ideológico por excelência" (VOLOSHINOV, 1929, p. 36; grifo do autor). Isso significa que ela se torna uma arena de lutas e tensões políticas, em que sentidos variados concorrem pela interpretação dominante, que se vincula a determinados gestos de 
leitura. Assim, a ideologia se materializa na língua, sendo a palavra um indicador dessa materialização ao preencher diferentes funções ideológicas, desde cotidianas e ficcionais até oficiais e normativas. Associado à palavra está o contexto sintático, que também será considerado em algumas análises feitas, pois conduzem a diferentes interpretações possíveis.

Sobre a esfera ideológica à qual a análise se vincula, consideramos que a escola está inserida dentro de um dispositivo estatal mais amplo e, sendo vista como um dos aparelhos ideológicos, tende a reproduzir as relações de exploração e de produção (ALTHUSSER, 2003). No contexto escolar, o livro didático assume um papel central na legitimação de saberes e na orientação de metodologias de ensino, embora alguns defendam que esse material deva operar apenas de maneira auxiliar e instrumental (LAJOLO, 1996). Nesse capítulo, trata-se de considerar o LD como um recurso gerido e administrado pelo Estado, não sendo, portanto, neutro em suas formulações. Exemplo disso é o Programa Nacional do Livro Didático (PNLD) ${ }^{125}$ que, além de ser o responsável pela compra e distribuição dos LDs, é também responsável pela emissão de pareceres sobre o seu conteúdo.

Tendo feita essa apresentação, o capítulo se organiza da seguinte maneira: inicialmente, discorre-se sobre o papel político dos livros didáticos na construção e legitimação de saberes; em seguida, procede-se à análise dos dados; por fim, reflete-se sobre a importância de se considerar a forma linguística (léxico) como lugares de inscrição de discursos e práticas racistas, atentando para a relação entre forma e conteúdo na construção de sentidos.

125 O programa de legislação do LD surgiu em 1929, incialmente com o nome de Instituto Nacional do Livro (INL). Foi criado para dar maior legitimidade ao livro didático nacional e, consequentemente, auxiliar no aumento de sua produção e distribuição. Informações complementares estão disponíveis em: <http://www.fnde.gov.br/programas/livro-didatico/livro-didatico-historico>. 


\section{Sobre a relação entre Estado e ensino}

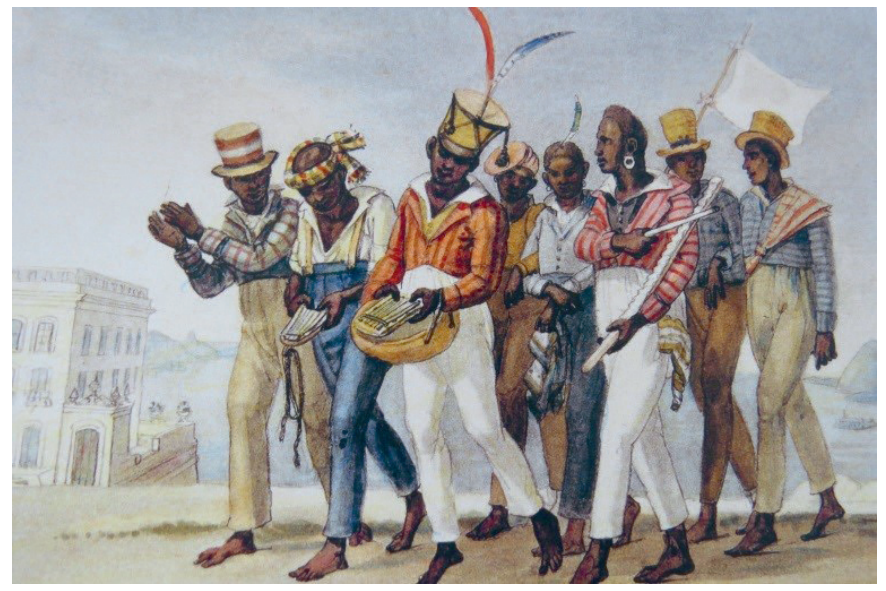

Figura 22.1 - Jean Baptiste Debret em "Viagem Pitoresca e Histórica ao Brasil", 1965.

O livro didático circula pelo mundo das práticas sociais letradas, resulta de relações de poder e tem por finalidade uma prática socioeducativa, posto que é elaborado, regulado, controlado, impresso e distribuído por sujeitos sociais e instituições que objetivam socializar fatos, acontecimentos, "verdades", ideias e conhecimentos para fins pedagógicos. Esse material tem sido, de forma geral, o único instrumento de apoio ofertado pelo Estado ao professor, se constituindo na principal fonte de estudo e pesquisa para os estudantes. A adoção do livro didático, contudo, é facultada ao professor, que tem liberdade para escolher o material que melhor se adapte a sua prática. E é a pretexto de auxiliar o professor na tarefa de selecionar o livro didático que o MEC disponibiliza um guia com resenhas que procuram retratar a estrutura e as características dos livros, além de um quadro com as avaliações. A execução dessas avaliações acontece em ciclos trienais alternados. Desse modo, a cada ano, a Fundação Nacional do Desenvolvimento da Educação (FNDE) adquire e distribui livros para todos os alunos de determinada etapa de ensino.

As reflexões deste capítulo inserem-se num campo fecundo para a exploração, especialmente porque a pesquisa no Brasil sobre racismo em livro didático pode ser considerada "reduzida e incipiente", segundo Bazilli, Rosemberg e Silva (2003). Outro dado importante levantado pelos autores, e que vale mencionar, diz respeito à dificuldade que professores apresentam em identificar a presença do racismo no livro didático, conclusão também da tese de doutorado de Ana Célia Silva (2001). Ainda no campo das pesquisas sobre o tema, nos influenciou o trabalho População negra brasileira: reflexos e imagem no livro didático (FREITAS; JESUS, 2011), que apontou uma relação entre a ausência de imagens dos negros 
nos livros didáticos e a discriminação no contexto social. Ainda nessa direção, a pesquisa de Costa (2006) concluiu que as imagens dos africanos nos livros didáticos são marcadas por violência.

Embora alguns trabalhos já tenham focado a análise do racismo no LD, conforme visto, o diferencial da nossa pesquisa se dá pela análise comparativa e histórica dos dizeres sobre o africano e afrodescendente nos LDs de história em três períodos marcados por princípios políticos divergentes. Espera-se verificar como se articula o percurso histórico e a legitimação desses discursos por meio de uma análise linguístico-discursiva.

Historicizando a relação entre LD e Estado, cabe destacar que a preocupação com sua produção entra na pauta de governo na década de 1930, sob forte controle, quando Vargas instituiu a Lei 1.006/1938, que "estabelece as condições de produção, importação e utilização do livro didático". Essa lei demonstra que os discursos veiculados no LD têm sua legitimidade validada pelo Estado desde o final da década de 1930. O Ministério da Educação foi criado em 1930, com o nome de Ministério da Educação e Saúde Pública. Cabia à instituição desenvolver atividades concernentes a vários segmentos, como saúde, esporte, educação e meio ambiente. Destacamos que, até então, os assuntos ligados à educação eram tratados pelo Departamento de Ensino, órgão ligado ao Ministério da Justiça. Somente em 1934, com a nova Constituição federal, a educação passou a ser vista como um direito de todos, devendo ser ministrada pela família e pelos poderes públicos. Gustavo Capanema foi o ministro da educação e saúde pública no período de 1934 a 1945, e sua gestão foi marcada pela reforma dos ensinos secundário e universitário. Nessa época, o Brasil já implantava as bases da educação nacional.

Em 10 de novembro de 1937, Getúlio Vargas, com apoio militar, implantou o que denominou Estado Novo, promulgando uma nova Constituição que fez desaparecer a exigência de um plano nacional de educação e desobrigou o Estado de oferecer o ensino público a todos. Diferentemente, a obrigação do poder público recairia sobre aqueles que demonstrassem insuficiência de recursos para se manter numa escola particular (PALMA FILHO, 2005). O Estado Novo também dissolveu todos os partidos políticos, dentre eles, o partido da Frente Negra Brasileira, criado em 1936 com o objetivo de reunir os movimentos negros visando à adoção de políticas reparadoras. Vejamos o depoimento de Aristides Barbosa, um dos integrantes do movimento:

a Frente Negra acabou por injunção política. Quando deu o golpe político de 1937, o Getúlio fechou também a Frente Negra, isso eu faço questão de dizer porque todo mundo pensa que o Getúlio fechou por preconceito, mas ele fechou porque tinha ostensivamente lá na porta: "Frente Negra Brasileira: Órgão Político e Social da Raça” (BARBOSA et al., 2012, p. 26). 
A partir disso, os movimentos negros tiveram que recuar para suas formas tradicionais de resistência, com ênfase no aspecto cultural. Nesse contexto, a União Negra Brasileira passou a ser intitulada como Clube Recreativo Palmares (BARBOSA et al., 2012, p. 28). Tal fenômeno também ocorreu no interior do estado de São Paulo. Podemos citar a criação da Sociedade Beneficente e Recreativa Estrela D'oriente, na cidade de Barretos, cujos objetivos, para além de oferecer espaço de lazer, visavam prestar apoio social e material aos seus associados. Dentre as motivações que levaram à criação dessa sociedade estava o preconceito, pois os negros da cidade não eram bem recebidos em salões frequentados por brancos (ARMANI et al., 2012).

Segundo os Parâmetros Curriculares Nacionais (1998), o ensino de história no contexto do Estado Novo tinha como tarefa enfatizar o ensino patriótico, capaz de criar nas gerações novas a consciência da responsabilidade diante dos valores maiores da pátria - a sua independência, sua ordem e o seu destino -, assim como enfatizar a comemoração de heróis em grandes festividades cívicas. Quanto à questão racial, o documento aponta que o discurso de "democracia racial" foi legitimado a partir de representações do africano como pacífico diante do "trabalho escravo".

Duas décadas depois, com o golpe militar em 1964, o Brasil passou a ser regido por atos institucionais, os chamados AIs. Três anos após o golpe, buscando dar legitimidade ao regime militar, em 1968, 190 decretos (AIs) foram incorporados ao que viria a ser a sexta Constituição do país e a quinta Constituição Republicana. A educação nessa constituição foi considerada um direito e deveria ser oferecida nas escolas, embora não se restringisse a esse espaço. Ainda em 1969, temos o Decreto-Lei $n^{\circ} .869$, de 12 de setembro de 1969, que dispõe sobre a inclusão da Educação Moral e Cívica como disciplina obrigatória, nas escolas dos sistemas de ensino do país. Em seu artigo $2^{\circ}$, que trata da finalidade da disciplina, tem-se: parágrafo h) o culto da obediência à Lei e da fidelidade ao trabalho (SEE, s/d, p. 5). Tal finalidade da Lei sinaliza para os objetivos políticos do período: a disciplinarização/docilização dos indivíduos e a normatização dos comportamentos da população voltados para a construção de uma sociedade capitalista. Destacamos que a Comissão Nacional de Moral e Civismo também tinha como responsabilidade o "exame dos livros didáticos" com a função de: organizar e submeter à aprovação do ministro da educação e cultura as instruções para exame de livros didáticos, do ponto de vista da Moral e civismo (SEE, s/d, p. 37).

Nos anos 2000, outro discurso oficial, agora com viés libertário, merece ser mencionado: trata-se da Lei 7.084/2010, que trata das políticas sobre o programa de material didático, postulando no segundo artigo, Dos objetivos dos livros didáticos: a democratização do acesso às fontes de informação e cultura. No embalo das leis, é importante mencionar a luta do Movimento Negro pela veiculação 
de representações positivas na esfera educacional e acadêmica, o que culminou com a criação da Lei 10.639/2003, que trata da obrigatoriedade do ensino da história e cultura afro-brasileira, visando, entre outros aspectos, à "afirmação de identidades; de historicidade negada ou distorcida". ${ }^{126}$ Essa lei foi alterada pela Lei $\mathrm{n}^{\circ} 11.645$, de 10 março de 2008, para incluir o ensino obrigatório da história e cultura afro-brasileira e indígena. Destacamos que o Estado brasileiro, impulsionado pelo Movimento Negro, também determinou a inclusão no calendário escolar do dia 20 de novembro como o "Dia da Consciência Negra". O Movimento Negro, junto com pesquisadores da área, tem cobrado dos poderes públicos a disponibilização de quadros preparados técnica e politicamente para fazer avançar a luta por uma educação voltada para a igualdade racial (CEERT, 2005, p. 14). Assim, faz parte da agenda de reivindicação do Movimento Negro uma revisão ampla da forma como os negros apareciam e, ainda hoje, aparecem retratados na História do Brasil (MEC, 2008, p. 10).

Essa contextualização ilustra que os discursos educacionais não são livres, mas controlados e administrados segundo diferentes propósitos estatais e governamentais. Diante disso, concordamos com Foucault (2009, p. 44), para quem "todo o sistema de educação é uma maneira política de manter ou de modificar a apropriação dos discursos, com os saberes e os poderes que estes trazem consigo". Tendo feito essa contextualização histórica que ilustra a relação entre Estado, educação e controle dos discursos escolares referente às três fases que compõem o corpus da pesquisa, seguem as análises dos usos lexicais e de expressões correlatas.

\section{Entre "escravo" e "escravizado": relações de poder inscritas na língua}

Reflexões sobre o papel político da língua na reificação de estereótipos, como a análise sobre o uso do termo "escravo" para designar o africano, já foram feitas por alguns pesquisadores, como Octavio Ianni (1966). Contudo, tais análises não foram suficientes para mudar as formas de designação dos africanos nos livros didáticos, conforme observamos. Notamos que o uso do termo "escravo" é recorrente nos meios de comunicação, tratando-se de um lugar comum sempre evocado pela mídia televisiva, jornalística e pelas esferas jurídica e escolar para

126 Parecer CNE/CP 003/2004 da professora Petronilha Beatriz Gonçalves e Silva. Diretrizes Curriculares Nacionais para a Educação das Relações Étnicorraciais e para o Ensino de História e Cultura Afro-Brasileira e Africana. Disponível em: http://portal.mec.gov.br/cne/arquivos/ pdf/003.pdf. 
representar determinadas condições de trabalho. Assim, essa temática se impõe diante dos contextos na atualidade que ainda reiteram construções linguísticas cristalizadas e naturalizadas. O enfoque sobre o uso dos termos "escravo" e "escravizado" implica inscrever os debates sobre preconceito e racismo no interior da própria língua.

Assim, analisando livros didáticos de história do ensino fundamental da década de 1930 até 2009, observamos que, de forma geral, o africano, quando discursivizado, tem a sua visibilidade inicialmente construída a partir do período da colonização e de uma ideia de subalternidade, como se a África não existisse anteriormente à colonização. Com isso, o africano passa a ser discursivizado a partir do sistema escravocrata e dos interesses econômicos dos colonizadores. Nesse contexto, esses sujeitos são designados pelo substantivo "escravo". Salienta-se, ainda, que há casos em que esse termo ocupa a função sintática de sujeito, apontando, paradoxalmente, para uma certa agentividade do africano diante de sua condição de escravo. Não por acaso, tais situações ocorrem com o uso de determinados verbos de ação, como em "eles chegaram" e "eles vieram", sinalizando para uma suposta vontade e ocultando as relações de exploração, conforme se lê abaixo (grifos nossos):

Registros oficiais informam que escravos de origem africana começaram a chegar ao Brasil em 1550 [...]. Os negros que vieram para cá faziam parte de dois grandes grupos culturais, de características físicas diferentes: os bantos e os sudaneses. (FIGUEIRA; VARGAS, 2009, p. 214).

Este outro exemplo ilustra o uso do mesmo termo “escravo" em situação sintática de objeto, destituindo o lugar de agentividade presente nos excertos anteriores:

As primeiras capitanias do Brasil que receberam escravos africanos foram Bahia e Pernambuco, onde a produção de açúcar mais prosperou. (COTRIM; RODRIGUES, 2009, p. 147).

Os destaques anteriores demonstram certa tendência para a naturalização da pessoa africana como "escrava". A alta frequência do uso desse termo, associando africanos à escravidão, produz uma linguagem naturalizada que oculta as assimetrias e relações históricas de poder, suavizando o sistema escravocrata implantado no país.

A título de comparação, o sujeito indígena tende a ser discursivizado a partir de uma outra chave interpretativa. Se os africanos entram na "ordem do discurso escolar" a partir do tema da escravidão, os indígenas são discursivizados a partir 
do contexto das descobertas. Os indígenas são apresentados em estado inicial de liberdade, como valentes e resistentes à escravidão, embora frágeis ao contato com o europeu, já que adoecem com facilidade. Diferente dos africanos, os indígenas são referendados pelo substantivo "escravizado". Essa variação lexical entre escravos e escravizados pode ser observada nos excertos a seguir:

Os portugueses que vieram ao Brasil para cultivar cana apelaram para a escravidão dos índios. Estes resistiram fazendo guerra aos colonos. [...] todavia, melhor preparados para a guerra, os colonos submeteram os indígenas. Milhares deles foram escravizados para trabalhar na lavoura para. [..] A partir de 1568 chegaram os primeiros escravos africanos. (PIMENTEL, 1979, p. 65-66).

A partir do século XVI, os colonizadores passaram a dar preferência aos escravos africanos [...]. Mas, durante o século XVII, a colonização avançou para o norte [...]. Lá os indígenas continuaram sendo caçados e escravizados, apesar da oposição dos jesuítas e da Coroa portuguesa. (FIGUEIRA; VARGAS, 2009, p. 211).

No início da produção de açúcar, no século XVI, os colonos encontraram uma solução barata [...] escravizar os indígenas. No começo do século XVII, contudo, a população nativa já se reduzira muito. [...] a coroa portuguesa buscou alternativas. A escolha recaiu sobre os africanos e deu origem ao lucrativo comércio de escravos entre o litoral da África e as capitanias do Brasil [...]. (COTRIM; RODRIGUES, 2009, p. 133).

Para sistematizar a análise referente ao uso variável dos termos "escravo" e "escravizado" e explicitar o tratamento diferenciado conferido aos indígenas e africanos, nossa análise demonstrou a seguinte ocorrência numérica nos livros didáticos analisados:

Tabela 22.1 -Uso diferenciado dos termos escravo e escravizado em LDs de História

\begin{tabular}{|c|c|c|}
\hline Africanos & Escravo $=30$ & Escravizado $=02$ \\
\hline Indígenas & Escravo $=0$ & Escravizado $=11$ \\
\hline
\end{tabular}

Considerando o contexto textual de uso dos termos, nota-se que os sentidos de escravo e de escravizado são naturalizados pelo campo semântico em que se enquadram: muitas vezes, a ideologia trabalhista tende a suavizar a dimensão exploratória e violenta que definiu a escravização. Os excertos a seguir revelam essa relação entre o uso do termo escravo e a ideia de "trabalho". 
Não se prestava o silvícola ao trabalho escravo. Amante da liberdade, acostumado à vida ao ar livre, à caça e à pesca, o indígena não poderia submeter-se, como o negro, ao trabalho servil para os conquistadores. [...] Os escravos africanos começaram a chegar em 1551 para trabalhar na lavoura [...] (LAUDES, 1974, p. 67-90).

Desde o século XV, os portugueses empregavam nas lavouras das ilhas da Madeira, Açores e Cabo Verde escravos africanos. Estes, em sua terra, praticavam a agricultura e a metalurgia (PIMENTEL, 1979, p. 65).

Uma análise comparativa entre indígena e africano revela o seguinte: enquanto o primeiro é representado como inapto para a exploração, o segundo é associado a uma cultura econômica de produção agrícola, o que justificaria a sua inclinação para a condição de escravização. Ainda no âmbito das relações de exploração, observamos outras diferenças de tratamento linguístico conferido aos indígenas e africanos. Tais diferenças revelam a construção e naturalização de estereótipos. Por exemplo, os africanos são, recorrentemente, retratados com os adjetivos "dóceis" e "resistentes", enquanto os indígenas são representados como "valentes" e "frágeis", posto que, "revoltam-se" e "adoecem":

Os colonos sem demora viram que os índios não suportavam o trabalho continuo e pesado a que os sujeitavam: revoltavam-se, adoeciam ou fugiam. Recorreram, então, aos escravos africanos, introduzidos na colônia desde seus primeiros tempos: eram servidores mais dóceis, mais ativos e resistentes (SILVA, 1938, p. 213).

Os africanos são descritos como "resistentes”, entretanto, são "dóceis/obedientes" em oposição à descrição dos indígenas, que, embora sejam "frágeis ao contato com os portugueses", são "revoltosos/valentes". Constrói-se, assim, duas visões diferentes de relações de escravização. Para marcar essa distinção, adotam-se dois termos: "escravo" e "escravizado". Na abordagem dos indígenas, os LDs salientam a força da opressão e da subjugação imposta a esses povos que "não suportavam o trabalho contínuo e pesado a que os sujeitavam". Já os africanos não são vistos nessa mesma chave interpretativa, havendo um apagamento da violência à qual foram submetidos. Assim, constrói-se linguisticamente um grupo como vítima, os indígenas, e outro como "solidário", os africanos, posto que estes não resistiam, não lutavam contra a escravização, mas mostravam-se como mais obedientes e "dóceis". O historiador Pinsky (1994b, p. 23) tenta justificar essa diferenciação entre indígenas e africanos: "o índio era visto em estado de liberdade, enquanto o negro, ao chegar aqui, já tinha passado pela experiência da captura, transporte através do mar e consequente desenraizamento, deslocado que era do seu habitat e de sua organização social”. Porém, ressaltamos que tanto 
os africanos como os indígenas foram aprisionados e violentados e, portanto, não encontramos diferenças na raiz da escravização (africana e/ou indígena) capazes de justificar a adoção de normas/termos distintos.

Reiterando, as escolhas lexicais mostram os indígenas como "altivos", "amantes da liberdade”, “acostumados à vida ao ar livre, à caça e à pesca” e, por isso, seriam "desacostumados" ao trabalho, "resistiam", "revoltavam-se”. Já os africanos viviam em cativeiro e, por isso, "não eram livres", eram "conformados" e "adaptavam-se ao trabalho servil". Paradoxalmente, essas características foram observadas nos textos de 1934, 1938, 1945, 1974, 1979 e 2009. Ou seja, mesmo após as Leis 10.639 e 11.645, observa-se o uso de expressões e adjetivações muito semelhantes às anteriores, o que sinaliza para a existência de uma memória discursiva colonial e colonizadora naturalizada pelos livros didáticos e cristalizada pelos usos lexicais e sintáticos feitos.

Reiterando, observamos que o uso dos termos "escravo" e "escravizado" permeia a tessitura dos discursos racistas sobre a relação entre os africanos e o Brasil colonial. Percorrendo o corpus de pesquisa que compreende períodos marcados por princípios políticos distintos (Era Vargas - Período Militar - Democracia), percebemos a estabilização (cristalização) do uso dos termos "escravizado" e "escravo", sendo que o termo "escravizado" tende a aparecer em associação ao indígena, enquanto o termo "escravo", ao africano. Nesse contexto colonial violentamente assimétrico, o branco é representado como o civilizador, colonizador, aquele que, para fazer a terra produzir "se vê obrigado" a escravizar índios e depois tem que "recorrer" ao "trabalho" do africano que é apresentado como escravo. Tem-se, assim, um exemplo de "racismo à brasileira" (DA MATTA, 1986), em que opera uma tendência a forjar "um sistema altamente hierarquizado" com fins de tornar a ideia de injustiça algo tolerável. Assim, numa sociedade hierarquizada/dividida, até a escravização obedece a este ideário. Com isso, constroem-se mitos distintos para a escravização indígena e a africana.

Além dos dados aqui analisados, outros pesquisadores brasileiros já assinalaram para o papel político do uso de certas formas lexicais ou construção sintática para se referir aos africanos no Brasil, como a pesquisa de Pinsky (1994) sobre o uso da voz ativa versus passiva para se referendar o deslocamento dos africanos para o Brasil, afinal eles não vieram, mas foram trazidos. Segundo o autor, "esta distinção não é acadêmica, mas dolorosamente real e só a partir dela é que se pode tentar estabelecer o caráter que o escravismo tomou aqui" (PINSKY, 1994a, p. 21). Entretanto, curiosamente, observamos na escrita do mesmo historiador que, embora ele seja um crítico de certos usos linguísticos, alguns deslizes escapam de seu controle, como o uso diferenciado dos termos "escravizado" e "escravo" para designar as condições do indígena e do africano, respectivamente. Seguem os excertos a título de ilustração (PINSKY, 1994a, grifos nossos): 
O índio, durante muito tempo, foi legalmente aprisionado no Brasil e escravizado (p. 10)

Lembramo-nos sempre da origem africana dos escravos (p. 23)

[...] o porto de origem do escravo (p. 24)

[...] os escravos eram geralmente prisioneiros de guerras (p. 23)

Apesar desse deslize lexical, é o próprio historiador (1994b, p. 23) quem nos oferece "pistas" para problematizar suas escolhas linguísticas: "na verdade, acabamos sendo devorados pela ideologia escravista que trata do negro como sendo 'naturalmente' escravo, ao contrário do índio." Aliás, torna-se, também, pertinente recuperar fragmentos da obra clássica de Gilberto Freyre (1984, p. 242) para ilustrar as mesmas acepções atribuídas ao indígena e ao africano: "o meio e as circunstâncias exigiriam o escravo. A princípio o índio. Quando este, por incapaz e molengo, mostrou não corresponder às necessidades da agricultura colonial - o negro".

Por fim, cabe uma pequena menção aos significados dicionarizados. Embora compreendamos que os dicionários tendem a cristalizar os sentidos, acreditamos ser pertinente uma breve análise das acepções atribuídas a esses dois termos, com fins de identificar em que medida esses instrumentos linguísticos incorporam, legitimando, esses sentidos políticos que, por vezes, são ocultados nos discursos historiográficos. Dentre os dicionários consultados - Pequeno Dicionário Brasileiro da Língua Portuguêsa (1943), Dicionário Escolar Latino (1956), Dicionário Prático da Língua Nacional (1969), Nôvo Dicionário Brasileiro Melhoramentos (1977), Mini Dicionário da Língua Portuguesa (2000), Minidicionário Enciclopédico Escolar (2003) e Dicionário Hoaniss (2009) - apenas o Mini Dicionário da Lingua Portuguesa (BUENO, 2000, p. 312) faz menção ao termo "escravizado", apresentando a seguinte definição: “Adj. Subjugado; tiranizado; cativado”. No Pequeno Dicionário Brasileiro da Língua Portuguêsa (LIMA, 1943), encontramos o verbo "escravizar", com a clara definição de: "subjugar; tiranizar; cativar; enlevar”. Em dois dicionários da década de 1970 - Dicionário Brasileiro da Língua Portuguesa (SILVA et. al, 1975) e Nôvo Dicionário Brasileiro Melhoramentos (SILVA, 1977) - identificamos o seguinte exemplo: "escravizavam os índios".

Quanto ao termo “escravo”, observamos a sua presença em todos os dicionários com uma acepção já padronizada, indicando que escravo é aquele que está sob o controle de outro. Percebemos, também, referência ao campo semântico do trabalho. Vejamos as definições: ${ }^{127}$

127 Definições referentes à consulta destes dicionários: Pequeno Dicionário Brasileiro da Língua Portuguêsa (1943), Dicionário Escolar Latino (1956), Dicionário Prático da Língua Nacional (1969), Dicionário Brasileiro da Língua Portuguesa (1975), Nôvo dicionário Brasileiro Me- 
adj. e s.m. Que, ou aquele que está sujeito a um senhor como propriedade dele;

Que, ou aquele que está absolutamente sujeito a outrem;

Que está sob o poder de um senhor;

Que, ou o que vive em absoluta sujeição a um senhor;

Que, ou aquele que está dominado por uma paixão ou por qualquer força moral: escravo dos seus deveres.

(fig). Dependente; rendido; enamorado.

Qualidade, sempre pronto para todo o tipo de trabalho.

Como exemplo, identificamos a seguinte construção no Mini Dicionário Enciclopédico Escolar (2003): "Em 1570 o Brasil tinha cerca de 3 mil negros escravos".

De acordo com as acepções encontradas, nota-se a definição recorrente de escravo como agente, aquele que se coloca nessa condição. Já o termo escravizado se remete à condição à qual o sujeito é submetido. A única exceção encontrada foi o dicionário Houaiss (2009), que designa "escravo" como uma situação involuntária, como estando "privado de liberdade”. É importante, também, observar que nas indicações dos dicionários, "escravizado" é classificado como adjetivo e, portanto, confere uma qualidade ou uma característica; já "escravo" tanto pode ser adjetivo quanto substantivo, ou seja, o termo pode definir a própria substância de um ser, nomeando-o.

\section{Palavras finais}

Este capítulo teve como objetivo analisar a maneira como certas construções ou usos linguísticos ratificam relações de poder coloniais, naturalizando-as. Tratou-se de analisar os usos dos termos "escravo" e "escravizado" em livros didáticos de história vinculados a três períodos históricos. Tais períodos constroem formas próprias de controle dos discursos a partir de uma articulação do Estado com programas de educação e de gerenciamento do livro didático. Identificou-se que os usos analisados foram recorrentes em todos os momentos analisados, fato que reitera uma memória colonial fortemente enraizada nos discursos e saberes que constituem e legitimam "regimes de verdade" (FOUCAULT, 2010). Considera-se que a análise da relação entre forma e conteúdo é necessária para desvelar os sentidos ocultados ou silenciados. Salienta-se, contudo, que outras pesquisas já ilustram pequenas mudanças nas formas de representação da cultura negra no Brasil: os trabalhos de Silva (2005) revelaram que, dos quinze livros de língua portuguesa de ensino fundamental $\left(1^{\circ}\right.$ e $2^{\circ}$ ciclos $)$ referentes à década de 1990

lhoramentos (1977), Mini Dicionário da Língua Portuguesa (2000), Minidicionário Enciclopédico Escolar (2003). 
analisados, cinco revelaram algumas mudanças mais significativas. O nosso foco, contudo, não foi a disciplina de língua portuguesa, mas de história, o que configura uma outra dinâmica disciplinar, pois lida com textos e imagens acadêmicos já consolidados pela historiografia canônica.

No caso deste capítulo, trata-se de propor como desafio a busca por novas formas de narrar - nos contextos acadêmicos e educacionais - a presença dos africanos no Brasil, bem como a sua história e origem. Essas formas de narrar devem, também, estar articuladas a novas representações imagéticas, em busca de uma ressignificação da nossa memória colonial verbal e visual.

\section{Referências}

ALTHUSSER, L. Aparelhos ideológicos de estado. 9. ed. São Paulo: Graal, 2003.

ARMANI, K. O.; FERNANDES, S. C. T.; TINELI, R.; TRUCULLO, P. Descobrindo Barretos: 1854 - 2012. Barretos: Liverpool, 2012.

BARBOSA, A.; LEITE, J. C.; LUCRÉCIO, F.; MOTTA, P. D.; RIBEIRO, M. O. Frente negra brasileira: depoimentos. São Paulo: Governo do Estado de São Paulo, 2012.

BAZILLI, C.; ROSEMBERG, F.; SILVA, P. V. B. S. Racismo em livros didáticos brasileiros e seu combate: uma revisão da literatura. Revista Educação e Pesquisa, São Paulo, v. 29, n. 1, p. 125-146, 2003.

BRASIL. Lei n ${ }^{\circ} 1.006$, de 1938. Estabelece as condições de produção, importação e utilização do livro didático. 30 dez. 1938.

BUENO, F. S. Dicionário escolar da língua portuguesa. 7. ed. Rio de Janeiro: Fename, 1956.

BUENO, S. Mini dicionário da língua portuguesa. 2. ed. São Paulo: FTD, 2000.

CARVALHO, J. M. Dicionário prático da língua nacional. 23. ed. São Paulo: Egéria, 1969.

CEERT. Políticas de promoção da igualdade racial na educação: exercitando a definição de conteúdo. 2005. Disponível em: < http://www.diversidadeducainfantil.org.br/PDF/ Pol\%C3\%ADticas\%20de\%20promo\%C3\%A7\%C3\%A3o\%20da\%20igualdade $\% 20$ racial\%20na\%20educa\%C3\%A7\%C3\%A3o.pdf >. Acesso em: 16 jun. 2016.

COSTA, W. As imagens da escravidão nos livros didáticos de história do ensino fundamental: representações e identidades. 2006. Dissertação (Mestrado) - UNIRIO, 2006.

COTRIM, G.; RODRIGUES, J. Saber e fazer história: história geral e do Brasil. 6. ed. São Paulo: Saraiva, 2009. 
DA MATTA, R. O que faz o Brasil, Brasil? Rio de Janeiro: Rocco, 1986.

FIGUEIRA, D. G.; VARGAS, J. T. Para entender a história. São Paulo: Saraiva, 2009.

FOUCAULT, M. A ordem do discurso. Tradução de Laura Fraga de Almeida Sampaio. 18. ed. São Paulo: Loyola, 2009.

. Microfísica do poder. Tradução de Roberto Machado. 28. ed. Rio de Janeiro: Graal, 2010.

FREYRE, G. Casa grande e senzala. 23. ed. Rio de Janeiro: Livraria José Olímpio, 1984.

FREITAS, M. D. S.; JESUS, N. F. 2011 "População negra brasileira: reflexo e imagem no livro didático". In: IV Encontro Estadual de Didática e Prática de Ensino, 2001, Goiânia. Goiânia. Disponível em <http://www2.unucseh.ueg.br/ceped/edipe/anais/ivedipe/ pdfs/historia/co/435-1101-1-SM.pdf>. Acesso em 18 set. de 2016.

HOAUISS. Dicionário Hoaniss eletrônico. Objetiva: 2009.

IANNI, O. Raças e classes sociais no Brasil. Rio de Janeiro: Civilização Brasileira, 1966.

LAJOLO, M. Em aberto: livro didático e qualidade do ensino. Brasília, DF: MEC, 1996.

LAUDES, Comissão Didática. Estudos sociais: história do Brasil até a independência, 1974.

LIMA, H. (Org.). Pequeno dicionário brasileiro da língua portuguêsa. 10. ed. Rio de Janeiro: Civilização Brasileira, 1943.

MEC. Dicionário escolar latino: português. 2. ed. Rio de Janeiro: Campanha Nacional de Material de Ensino, 1956.

MEC. Parecer CNE/CP n ${ }^{\circ}$ 003, de 2004. Diretrizes curriculares nacionais para a educação das relações étnico-raciais e para o ensino de história e cultura afro-brasileira e africana.

In: _. Contribuições para implementação da Lei no 10.639, de 2003. Brasília, DF: 2008. Disponível em: <http://portal.mec.gov.br/index.php?option=com_ docman\&view=download\&alias=1851-lei10639-pdf\&category_slug=novembro-2009pdf\&Itemid=30192>. Acesso em: 16 jun. 2016.

MOREIRA, K. H. 2008. "Pesquisa em história da educação: localização e seleção de livros didáticos de história republicanos”. In: Congresso Brasileiro de História da Educação. Aracaju. Disponível em: <www.sbhe.org.br/novo/congressos/cbhe5/pdf/367.pdf>. Acesso em: 16 jun. 2016.

PAINE, T. Senso comum. São Paulo: Ibrasa, 1964.

PIMENTEL, W. J. Estudos sociais: história do Brasil. São Paulo: Ibep, 1979. 
PINSKY, J. (Org.). O ensino de história e a criação do fato. 6. ed. São Paulo: Contexto, 1994.

- A escravidão no Brasil: a escravidão acabou? A vida cotidiana dos escravos. 13. ed. São Paulo: Contexto, 1994.

ROCHA, R.; PIRES, H. S. Minidicionário enciclopédico escolar. 10. ed. São Paulo: Scipione, 2003.

SILVA, A. C. A desconstrução da discriminação no livro didático. In: MUNANGA, K. (Org.). Superando o racismo na escola. 2. ed. Brasília, DF: Ministério da Educação, 2005.

SILVA, A. P. et al. Dicionário brasileiro da língua portuguesa. S.1.: Mirador, 1975.

SILVA, A. P. Nôvo dicionário brasileiro Melhoramentos. 6. ed. São Paulo: Melhoramentos, 1977.

SILVA, J. História da civilização. S.l.: S.e., 1938.

VOLOSHINOV, V. N. Marxismo e filosofia da linguagem. São Paulo: Editora Hucitec, 2006. 